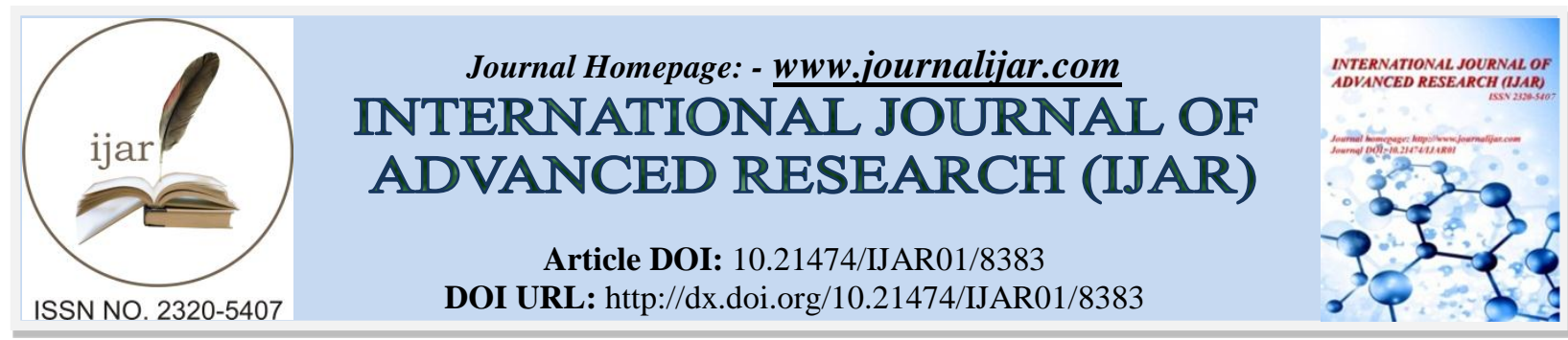

RESEARCH ARTICLE

\title{
ASSESSMENT OF HAEMATOLOGICAL INDICES AND DNA PATTERN IN LEUKAEMIA PATIENTS KADUNA NIGERIA
}

Oledinma $S^{1}$, Emelike O.F ${ }^{2}$ and Akpulu S.P ${ }^{3}$.

1. Department of Hematology, School of Medical Laboratory Sciences, Ahmadu Bello, University Teaching Hospital Zaria, Nigeria

2. Department of Haematology, Faculty of Basic Medical Sciences, College of Medicine, Ambrose Alli University, Ekpoma, Edo State-Nigeria.

3. Department of Human Anatomy, Faculty of Basic Medical Sciences, College of Medicine, Ahmadu Bello University Zaria, Nigeria.

\section{Manuscript Info}

Manuscript History

Received: 12 November 2018

Final Accepted: 14 December 2018

Published: January 2019

Key words:-

Leukaemia, PCR, DNA Pattern,

Hematological parameters.

\section{Abstract}

Leukaemia is the general name given to a group of cancers that develop in the bone marrow. It originates in developing blood cells that have undergone a malignant change leading to multiple uncontrolled malfunctioning cells. The end result include fatigue, weight loss, frequent infections and easy bleeding or bruising. The search for accurate information, data and solution is still a challenge to many developing countries like Nigeria. The study therefore reported the assessment of hematological parameters and DNA pattern in leukaemia patients attending hemato-onchologyclinic of Ahmadu Bello University Teaching Hospital (ABUTH) Zaria, Kaduna State Nigeria. 500 suspected leukemia patients attending haemto-oncology clinic of ABUTH from March 2015 to October 2018 were included in the study. $3 \mathrm{~mL}$ of the patients' blood were collected into EDTA bottles and analysed for full blood and differential count using automated blood counter and also thin blood smear were made, stained and examined for leukemic cells. The DNA were confirmed using polymerase chain reaction assay. Data were subjected to simple statistical analysis and results recorded. Full blood count and cytomophological method detected $30(6 \%)$ prevalence of leukemia while PCR assay detect 28 (5.6\%) prevalence in Kaduna State. The pattern of leukaemia DNA detected include $2.8 \%$ in Kaduna North district, $1.8 \%$ in Kaduna South District and $1 \%$ in Kaduna central district respectively. Decreased platelet count, packed cell volume and increased white blood cell count and presence of blasts and smudges cells were significant $(\mathrm{P} \leq 0.05)$. The molecular pattern of leukaemia and the prevalence were significant $(\mathrm{P} \leq 0.05)$ in Kaduna State, Nigeria. The presence of abnormal DNA and some hematological parameters is related to leukaemia infection in Kaduna state Nigeria.

Copy Right, IJAR, 2018, All rights reserved.

Corresponding Author:-Oledinma S.

Address:-Department of Hematology, School of Medical Laboratory Sciences, Ahmadu Bello, University Teaching Hospital Zaria, Nigeria. 


\section{Introduction:-}

The developing world, especially Africa is witnessing an alarming upsurge of Leukaemia incidence. The annual number of new cancer cases is expected to double by $2020^{24}$. Leukaemia are neoplastic clonal disorder of haemopoietic tissues in which a stem cell or other precursor of blood cells in the bone marrow or lymphoid tissues proliferate ${ }^{17}$.Molecular epidemiology is the study of the genetic and environmental causes of disease and both their interactions together to understand clinical risks, outcome and prevention of disease ${ }^{32}$. Initially, while investigation began into the molecular epidemiology of leukaemia, one of the approaches was to explore specific candidate genes that could contribute to leukaemia risks.

Hematological markers abnormalities such as low platelet count and hemoglobin can predisposed patients from minor bleeding to massive life-threatening hemorrhage ${ }^{21}$. The presence of blast cells and smudge cells in peripheral blood stained film is evidence of leukemia infection and these parameters are used as prognostic indices of leukaemia infection ${ }^{29}$. Thrombocytopenia is a common feature of liver diseases in leukemia infection in 30 to $64 \%$ ${ }^{10}$. Spleenomegaly is considered the main cause of low platelet count in acute leukemia. Polymerase chain reaction assay with specified markers that detected DNA has been related to hematological parameters in leukemia patients and considered as evidence of the infection ${ }^{42} 44$.

Using technological approaches available such as folate metabolism, genetic instability, bone marrow failure, immunodeficiency syndromes and transcription factor syndromes ${ }^{46}$. Applications of molecular methods of leukaemia diagnosis could resolve many problems associated with the cytomorphological method in Africa. Leukaemia is a global challenge. Griffin $e t$ al, reported in his studies that incidence of chronic myeloid leukaemia (CML) is estimated at 4 cases per 100,000 and acute myeloid leukaemia (AML) at 2.2 per 100,000 patients ${ }^{26}$. It was reported in 2004 that in the United State of America, estimated number of new CLL cases was 7,200. ${ }^{17}$.

In Europe, CML comprises only around $2-3 \%$ of all the leukaemia diagnosed in patients $<20$ years of age but the incidence increases with age slowly until the mid-40s, then more rapidly from about one per 100000/year in children $<10$ years to two per 100000 in people in the fifth decade to one per 10000 at age 80 . The disease is more common in males ${ }^{26}$. Durosinmi (2008) in his handbook of haemoto-oncology stated that the incidence of CLL is quite high in Africa with about $40 \%$ of all cases of leukaemia in Ile-Ife, Nigeria, while Omoti (2005) observed that in the NigerDelta region of Nigeria, the incidence of CML was the most frequent subtype with 33.3\%, CLL with 20.8\%, prolymphocytic leukaemia (PLL) with 20.8\%, acute myeloid leukaemia (AML) with 16.7\% and ALL with $8.3 \%$. Most of these observation in Nigeria was based on the haemotological and clinical features. In this study, hematological abnormal parameters and DNA in leukemia patients were investigated. The study reported the assessment of hematological parameters and DNA pattern in leukaemia patients attending hemato-onchologyclinic of ABUTH Zaria, Nigeria.

\section{Materials and Methods:-}

This study was carried out in Ahmadu Bello University Teaching Hospital Zaria from March 2015 to October 2018. Biodata was collected from 500 clinically suspected leukemia patients attending haemto-oncology clinic using structured questionnaires. Among clinically suspected leukemia subjects, only laboratory diagnosed leukemia patients of either sex within the age 2-60 years were included in the study. All selected leukemic patients were investigated for hematological abnormalities and DNA study. $3 \mathrm{~mL}$ of the patients' blood were collected into EDTA bottles, gently mixed and within one hour analysed for full blood and differential count (total white blood cell count (WBC), platelet count, pack cell volume (PCV), hemoglobin ( $\mathrm{Hb})$ and differential leucocytes count) using automated hematology analyzer (sysmexKx-21), manufactured by sysmex cooperation Kobe, Japan. Also thin blood smear were made and cytomopholocial examination of Lieshman stained slides were recorded. Polymerase chain reaction assay: the gene of leukemia types was used as a target for amplification. This was carried out in a DNA thermal cycler types $480^{\mathrm{T} 0}$ (Pakon Elmer, countaboeuf France). Specific PCR was performed using the primers designed by Williams ${ }^{34} 56$, electrophoretic patterns of leukemia DNA were analyzed by gel electrophoresis using $1.5 \%$ agarous, stained with ethidum bromide. The bands were read using the $100 \mathrm{bp}$ plus ladders as marker and vissualised using altraviolet (UV) light ${ }^{38}$. 
Study results were analyzed by using statistical package for social science (SBSS) version 16 software. Simple frequencies, percentage, means \pm SD and association between hematological abnormal parameters and DNA assay using polymerase chain reaction with $95 \%$ confidence interval.

Ethical approval: Ethical approval for the study was gotten from the ethics review committees (ERC) of the Ahmadu Bello University Teaching Hospital Shika Zaria.

\section{Results:-}

Table 1:-Molecular prevalence of leukaemia among patients in relation to socio economic and demographic factors

\begin{tabular}{|c|c|c|c|c|}
\hline Factors & Number & PCR & Prevalence & P. value \\
\hline & examined & \multicolumn{2}{|l|}{ positive $(\%)$} & $\mathrm{p}<0.05$ \\
\hline Sex & & & & 0.228 \\
\hline Male & 300 & 20 & 4 & \\
\hline Female & 200 & 8 & 1.6 & \\
\hline \multicolumn{5}{|l|}{ Educational status } \\
\hline Informal & 140 & 8 & 5.7 & 0.046 \\
\hline Primary & 10 & 2 & 2.0 & \\
\hline Secondary & 150 & 6 & 4 & \\
\hline Tertiary & 200 & 12 & 6 & \\
\hline \multicolumn{5}{|l|}{ Occupation status } \\
\hline Unemployed & 20 & 0 & 0 & 0.0186 \\
\hline Student & 100 & 5 & 5 & \\
\hline Civil servants & 180 & 10 & 5.5 & \\
\hline Business & 80 & 5 & 6.2 & \\
\hline Artisans & 50 & 0 & 0 & \\
\hline Farmers & 70 & 8 & 11.4 & \\
\hline \multicolumn{5}{|l|}{ Social factor (habit) } \\
\hline Smoking & 200 & 12 & 6 & 0.707 \\
\hline Drinking of alcohol & 120 & 6 & 10 & \\
\hline None & 180 & 8 & 4.4 & \\
\hline
\end{tabular}

Table 1:-showed significant differences $(\mathrm{P} \leq 0.05)$ between education and occupation. Even though sex and social factors are not significant the male patient $4 \%$ and alcohol drinkers $(10 \%)$ seems to be more prone to infection. This result also revealed that tertiary $(60 \%)$ and informal $(5 \%)$ education were more affected with leukaemia disease.

Table 2:-comparative prevalence of cytomorphological and PCR assay in the in three senatorial districts of Kaduna State

\begin{tabular}{|c|c|c|c|c|c|}
\hline Senatorial & Number & Blood film & p. value & PCR & p. value \\
\hline Districts & examined & positive (\%) & p. $<0.05$ & positive & p. $<0.05$ \\
\hline Kaduna north & 220 & $16(3.2 \%)$ & 0.050614 & $(2.8 \%)$ & 0.0416 \\
\hline Kaduna south & 180 & $9(1.8 \%)$ & & $9(1.8 \%)$ & \\
\hline Kaduna central & 100 & $5(1 \%)$ & & $5(1 \%)$ & \\
\hline Total & 500 & $30(6 \%)$ & & $28(5.6 \%)$ & \\
\hline
\end{tabular}

Table 2: Indicate significant difference $(\mathrm{P} \leq 0.05)$ in both cytomorphological and PCR assay. Generally, result also showed that Kaduna North senatorial district 16(3.2\%) has high prevalence of leukaemia followed by Kaduna South district $9(1.8 \%)$. This is probably due to urbanization associated with population density, indusial waste, social 
factors like smoking and drinking of alcohol. The cosmopolitan nature of Kaduna central senatorial district associated with institutions of learning and civil servant may have been responsible for reduce infection.

Table 3:-Comparison of haematotological parameters of leukaemic patients with controls (normal subjects) Parameters

\begin{tabular}{|lllll|}
\hline & Test & Controls & T.Value & P.Value \\
\hline & $(\mathbf{n - 2 8})$ & $\mathbf{( n - 5 0 )}$ & & \\
\hline $\mathrm{Hb}$ & & & & \\
\hline Pcv(1/1) & 9.5 & 13.3 & 3.5 & 0.014 \\
\hline Wbc $(109 / 1)$ & .17 & .39 & 3.8 & 0.009 \\
\hline Platelets(10 $/ 1)$ & 111 & 4.5 & -2.31 & 0.04 \\
\hline Neutrophils (\%) & 118 & 134.3 & 1.1 & 0.04 \\
\hline Lymphocytes (\%) & 33 & 51 & 2.15 & 0.04 \\
\hline Eosinophils (\%) & 33 & 42 & 1.57 & 0.02 \\
\hline Monocytes (\%) & 23 & 3.0 & .98 & 0.007 \\
\hline Lymphoblast(\%) & 3.0 & 2.0 & 0.75 & 0.484 \\
\hline Myeloblast $(\%)$ & 31 & 0 & -1.04 & 0.339 \\
\hline Metamylocytes(\%) & 13. & 0 & -1.86 & 0.012 \\
\hline
\end{tabular}

Key: HB = Haemoglobin, $\mathrm{PCV}=$ Packed cell volume, $\mathrm{WBC}=$ White blood cell

PLT $=$ Plateletes, NEU $=$ Neutrophils, LYM = Lymphocyte, $\mathrm{MO}=$ Monocyte, EOS $=$ Eosinophils, $\mathrm{BOSO}=$ Bosophils, LYMb = Lymphoblast, MYEb= Myeloblast, METAm = Metamyelocyte

Table 3: showed significant difference $(\mathrm{P} \leq 0.05)$ among hematological parameters of leukaemia patients compared to normal individuals with the exception of monocytes, lymphoblast and metamyelocytes. Haemoglobin (9.5 gldl) and PCV $(0.27 \mathrm{~L} / \mathrm{L})$ values where less in leukaemia patients than in control. This implied that the patients where anaemia. The high value of WBC $\left(111 \times 10^{9} / \mathrm{L}\right)$ indicated high proliferation of abnormal WBC which reduces body immunity. Furthermore in this study, reduced platelet count $\left(118 \times 10^{9} / \mathrm{L}\right)$ is an index of defect in coagulation system of the patients the presence of blasts and smudge cells in the peripheral blood film was evidence indicating leukaemia infection.

Fig 1 A \& B:-DNA fragments amplification using OPA-09 primers on the leukaemic patients

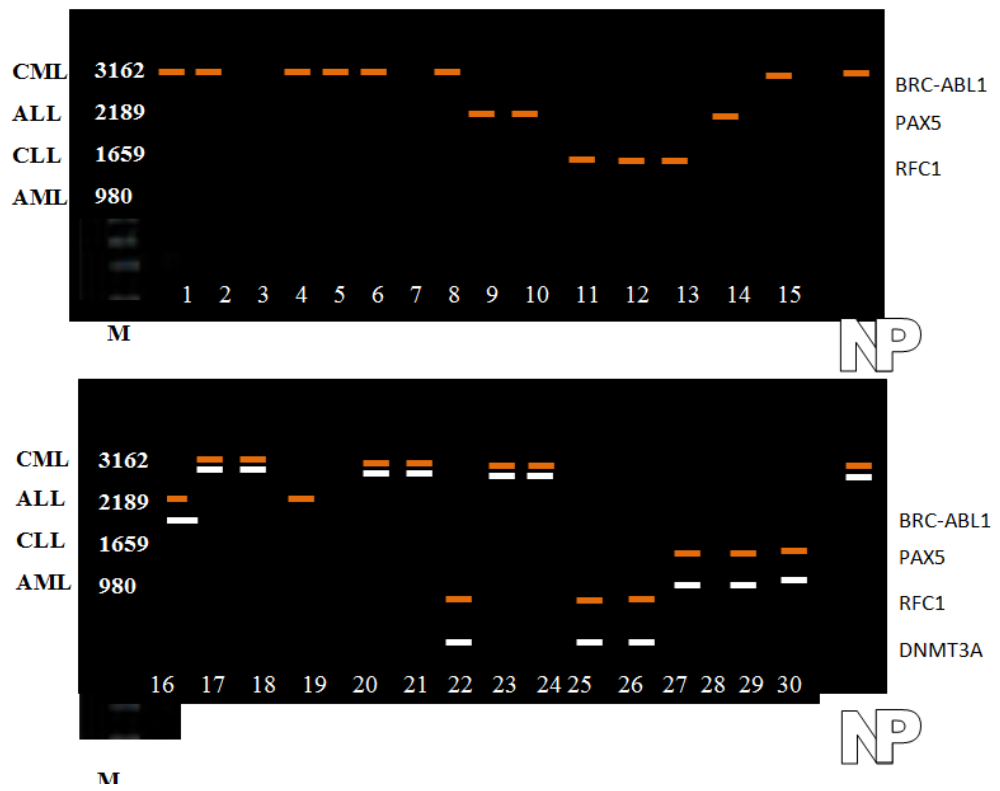




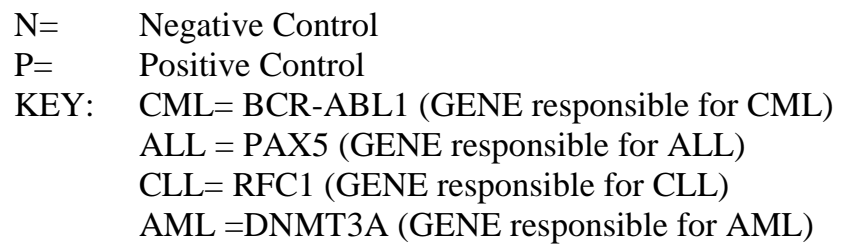

Fig 1A \&B: showed the DNA pattern of leukaemia, and out of the 30 blood samples detected positive of leukemia by cytomorphological method, 28 were confirmed positive for leukaemia while 2 blood samples were negative for leukaemia using polymerase chain reaction assay. The DNA fragments amplification indicated different base pairs (fig1 A). The base pairs ranged from 980 to 3162 which was used to group or determine leukaemia pattern. Results showed 3 chronic CML which amplified at the same level with the ladder at $3162 \mathrm{bp}$. Six patients each indicated ALL and CLL while three patients showed AML disease. It is therefore clear that PCR assay result eliminated two patients detected positive leukaemia using the gold method. Generally, high CML was observed in the study area within the period under review. The use of PCR also indicated high sensitivity and efficiency in the detection of leukaemia.

\section{Discussion:-}

This study revealed that male suffers slightly more with leukemia infection than female (male/female ratio was 3:1): more so in the middle age group between $42 \pm 19$ years. Decrease $\mathrm{Hb}$ and PCVhas been associated with anaemia and also DNA in leukemia patients. This study reported that majority of leukemia patients have decrease non-significant $(\mathrm{P} \geq 0.05)$ platelet count $(\mathrm{n}=28)$ and presented with bleeding. Increased white blood cells count was found to be associated with leukemia infection. Possible explanation may be due to proliferation of abnormal white blood cell in the bone marrow ${ }^{12}{ }^{39}$,never the less, these parameters do give a good estimate of the synthetic function of the organs and may still be used as prognostic markers ${ }^{22}$. In this studies $6 \%$ prevalence of leukemia were detected using cytomorphlogical method and 5.6\% prevalence by PCR assay this observation is in agreement with $6.2 \%$ reported in northern part of Nigeria ${ }^{4}, 7.3 \%$ prevalence in southern region of Nigeria ${ }^{21}$ and $3 \%$ prevalence in Uganda ${ }^{23}$. However our value is lower than $34 \%$ prevalence in Edo state, ${ }^{41}, 32 \%$ reported in south western region of the country ${ }^{21}$. The molecular prevalence of leukemia in Kaduna State districts showed that Kadaun North district had the highest prevalence of $2.8 \%$, followed by Kaduna South district with $1.8 \%$ and kaduna central district with the least of $1 \%$,this maybe probably due to urbanization associated with population density, industrial waste, social factors like smoking and drinking of alcohol. This is in line with the report of Ahmed et $\mathrm{al}^{4}$ and motiet al 42,34. The thrombocytopenia reported in this study also could be an increased platelets sequestration in the spleen due to congestive splenomegaly. A positive relationship between decrease platelet count, blast cells and abnormal DNA was found in this study. Similar findings were reported in previous studies ${ }^{33} 39$. There were significant difference $(\mathrm{P} \leq 0.05)$ in both cytomorpholocial and PCR assay. However PCR assay was more sensitive than the gold method. This was evidence in Kaduna North where the gold method detected $3.2 \%$ positive leukemia patients $(\mathrm{P} \leq 0.05)$ and was reduced to $2.8 \%(\mathrm{P} \leq 0.04)$. The $0.4 \%$ difference were not infected as indicated by gold method. There is significant difference $(\mathrm{P} \leq 0.05)$ among hematological parameters of leukemia patients with the exception of monocycle, lymphoblast and metamyelocytes. Hemoglobin $(9.5 \mathrm{gdl})$ and PCV $(0.27 \mathrm{~L} / \mathrm{L})$ values were less in leukaemic patients than in control. The high value of $\mathrm{WBC}\left(111 \times 10^{9} / \mathrm{L}\right)$ and reduce platelet count is an index of leukaemia infection.

\section{Conclusion:-}

This study therefore Concluded that hematological parameters related to DNA pattern in leukaemic patients in Kaduna State Nigeria is high.

\section{Recommendation}

We recommend that DNA pattern of different types of cancer study should also be carried out in Kaduna state

\section{Conflicts of interest}

The authors declare that there is no conflict of interests in the publication of this paper. 


\section{Acknowledgement:-}

The authors sincerely thanks all leukemia patients and staff of the haemato-oncology unit in Ahmadu Bello University Teaching Hospital Shika Zaria who took part in the study. Authors also acknowledge the staff of research laboratory of the Ahmadu Bello University Teaching Hospital and biotechnology research laboratory Ahmadu Bello University Zaria Nigeria.

\section{Reference:-}

1. Ahmed, S.G. and Ibrahim, U.A. (2006) Fibrin Degeneration Products in Hyperleuocytic Chronic Myeliod Leukaemia Pakistan Journal of Biological Sciences 9(12) 2354 - 2357

2. Abdel-Rahman, S.Z., El-zein,R.A., Anwar,W.A, and Au,w.w.(1996). A multiplex PCR procedure for polymorphic analysis of GSTMI and GSTTI genes in population studies. Cancer Journal: 107: 229-233

3. Abuidris, D.O., Ahmed, E.M. Elgaili, O. and Arora. R.S. (2008). Childhood cancer in Sudan: 1999-2007. Tropical Journal of Medicine 38: 208-210

4. Babatunde, A., Amiwero, C., Olatunji, P., and Durotoye, I. (2009). Pattern of Haematological Malignancies in Ilorin Nigerian: A ten year review. The Internet Journal of Haematology 5 (2), ISSN 1540-2549

5. Besson, C., Gonin, C., Brebion, A., Delaunay, C., Panelatti, G., and Plumelle, Y. (2001). Incidence of Haematological malignancies in Martinique, French West Indies. Leukaemia. 15 (5): 828-31.

6. Caligaris-cappio F. (2000). Auer Rod which maybe promyelocyte and myelocyte In: Biology of chronic lymphocytic leukaemia. Journal of Clinical Haematology 4:5-21.

7. Cartwright, R.A., Gurney, K.A., and Moorman, A.V. (2002). Sex ratios and the risks of haematological malignancies. British Journal of Haematology. 284 (6): 182-198.

8. Dacie, J.V., and Lewis, S.M. (1994). Haematological Parameters Changes in Chronic Myeloid Leukaemia IN: Practical Haematology $8^{\text {th }}$ edition, Churucill Livingstone (EBLBS) Edition. Page $13-17$.

9. Dollinger, M., Rosenbaum, E.H., and Tempero, M. (2007). Every Ones Guide to Cancer Therapy, Kansas city, Second Edition Page 286-320 Missouri; Andrews Mcmeel publishing.

10. Dansey, R., (2000) Myelodisplasia, transformation of chronic leukemia. Opinon oncology. 12:13-21

11. Else, M., Ruchlemer, R., and Osuji, N. (2005) Long Remissions in Hairy Cell Leukaemia with Purine analogs Cancer 104 (110) $2442-2448$.

12. Faderl, S., Talpaz, M., Estrov, Z., O’Brien, S., Kurzrock, R. and Kantarjian, H.M. (1999). The biology of chronic myeloid leukaemia. New England Journal of Medicine 341 (3): 164-172.

13. Griffin, P., Rodgers, A. and Neals Young (2005) lukaegenesis in leukaemia In: hand book of clinical hematology $2^{\text {nd }}$ edition pg. 107 lippincott and Williams publishing.

14. 26. SwerdlowS.H, Campo, E. Haris N.L.Jeffe, E. S. and Pilerisa S. A. (2008) WHO Classification tumors Haemopoietic and lymphoid tissue $4^{\text {th }}$ edtion vol.2.

15. Hoffbrand, A. V., and Pettit, J.E. (2006) hematological parameters in leukemic patients In: Essential Haematology, fifth edition, page 159 Blackwell scientific publications.

16. Marshall, A.L, Bentler, Thomas, J.K, Uri, S, Kenneth, K, and Joseph, T.P., (2006). Abnormal high level of WBC in peripheral blood In: Williams Haematology, seventh edition, page 201-210 McGraw-Phill Medical Publishing Division.

17. Morton, L.M, Wang, S.S, Devesa, S.S, Hartge P, Weisenburger, D.D and Linet, M.S. (2006) Lymphoma Incidence patterns by WHO subtype in the United States, 1992-2001. Blood.

18. Melo, J.V, Catovsky, D, and Galton, D.A., (1986). The relationship between chronic lymphocytic leukaemija and laboratory features of 300 patients and characterization of an intermediate group. British Journal of Haematology 83:358-426.

19. Omoti, C.E, Awodu, O.A., and Bazuaye, G.N., (2007). Chronic Lymphoid Leukaemia: clinic-haematological correlation and outcome in a single institution in Niger Delta region of Nigeria. International Journal Lab Hematology. 29 (6): 426-432.

20. Omoti, C.E., (2006). Socio-demographic factors of adult malignant lymphomas in Benin City Nigeria. Nigeria Postgrad Medical Journal 13 (3): 256-260.

21. Williams, J.G.K., KubelikA.R., Livak, K.J. RafalskiJ.A. and Tingey, S.V., (1990). DNA polymorphism amplified by arbitrary primers are useful as genetic markers. Nucleic Acids, 18: 6531-6535. 